\title{
NUTRITIONAL STUDIES ON THE UTILIZATION OF VETIVER PLANTS (VETIVERIA ZIZANIOIDES L.) AS A NON -CONVENTIONAL FEED-STUFF FOR FEEDING SMALL RUMINANTS
}

\author{
Afaf Abd El Rahman El Shereef (EL Shereef A. A. ) 1 and Mohamed Farag Shehata ${ }^{2}$
}

\begin{abstract}
Affiliation:
1. Animal and Poultry Nutrition Department, Desert Research Center, El-Matareya, Cairo, Egypt

2. Animal and Poultry Breeding Department, Desert Research Center, El-Matareya, Cairo, Egypt
\end{abstract}

Email:afafelshereef@gmail.com

\section{ABSTRACT}

The present study was conducted to estimate the nutritive value of vetiver plants (Vetiveria zizanioides L.) with different levels of concentrates (30, 50 and $70 \%$ of DM) compared to clover hay. In vitro dry matter disappearance (IVDMD) and organic matter disappearance (IVOMD) were determined. Vetiver grass was planted at Middle Sinai research station (El-Maghara) and produced 2.14 ton/feddan. The chemical composition showed that Vetiver grass had 10, 24.6 and $3.2 \%$ as crude protein, crude fiber and lipids contents. Metabolizable energy recorded higher values for vetiver grass compared to clover hay (2.05 vs $1.83 \mathrm{Mcal} / \mathrm{kg}$ DM). The IVCPD, and total gas production were significantly increased with increasing the level of concentrates. The results suggested that vetiver grass is a promising feed resource for feeding small ruminants under desert conditions in Sinai. While, in vivo studies are needed to estimate their actual nutritive values and their effects on animal performance.

Key words: vetiver grass, chemical composition, digestibility, gas production. 


\section{Introduction}

The variety on the natural feed resources soughs have motivated nutritionists to use nonconventional fodder plants as a part of the animal feed. Vetiver grass (V. zizanioides) is a perennial grass of the family Poaceae, which is originated from Southeastern Asia, India and tropical Africa. In mid-eighties vetiver grass was developed by the World Bank for soil and water conservation in India (Akhzari et al., 2013). At present, there are more than 100 countries cultivating and using vetiver (Chen, 1998). Some studies (Lavania, 2003) assed the potential utilize of vetiver grass as commercially herbage for produce the scented oil that can be distilled from its roots. Other studies emphasized its effectiveness in erosion, sediment control, and to be highly tolerant to extreme soil conditions (Balasankar et al., 2013). Vetiver grass may also be a promising feed resource because it has various advantages such as high quality, fast growth rate and easy adaptation to the environment and can bear repetitive mowing without occupying farming land (Ahmadi Beni et al., 2014). However, there is limited information on their nutritive value and the utilization of this grass as animal feed. Therefore, the present study amid to estimate the nutritive value of vetiver grass to provide support for future applications for feeding ruminants.

\section{Material and Methods Experimental grass preparation}

The experimental field work was conducted in Middle Sinai research station (El-Maghara), Desert Research Center, Egypt and was divided into two parts. The first part included cultivating vetiver grass while the second part included nutritional evaluation of the cultivated grass with different levels of concentrate feed mixture $(30,50$ and $70 \%$ of DM) compared to clover hay as traditional forage at in vitro level. Vetiver grass was planted in rows $75 \mathrm{~cm}$ apart and spaced $50 \mathrm{~cm}$ within the same row. The main source of irrigation was the ground water of which total dissolved salt ranged from 2500 ppm to 3000 ppm. The first cut was taken after a year of planting. The plant reached a height of $103 \mathrm{~cm}$ and produced 2.140 ton/ feddan under desert conditions in the middle Sinai station farm. The whole plant except roots were harvested, chopped $(3-5 \mathrm{~cm})$ then samples were dried at $50^{\circ} \mathrm{C}$ for $48 \mathrm{~h}$ using a forced air oven to prevent enzymatic degradation of the phenolic compounds present in the plant matter. Once dry, $200 \mathrm{~g}$ of plant matter was ground and sieved through a 2-mm screen. The grounded material was mixed well and then $100 \mathrm{~g}$ were sub-sampled, reground and passed through a $0.5-\mathrm{mm}$ screen sieve. These finely ground subsamples were used in tannin analysis while the rest of the material was used for in vitro gas production analysis. Samples of concentrate mixture (CM), consisted of $25 \%$ cotton seed cake $+30 \%$ corn $+35 \%$ wheat bran $+3 \%$ rice straw $+3 \%$ molasses $+1 \%$ urea + $2 \%$ limestone and $1 \%$ common salt, were mixed with vetiver samples at level of 30 (D1), 50 (D2) and $70 \%$ (D3) of DM. Representative samples of vetiver grass hay, clover hay, concentrate mixture and the experimental diets (D1 consisted of $30: 70 \mathrm{CM}$ : vetiver grass, D2 consisted of $50: 50 \mathrm{CM}$ :vetiver grass and $70: 30 \mathrm{CM}$ : vetiver grass was taken for analysis. 


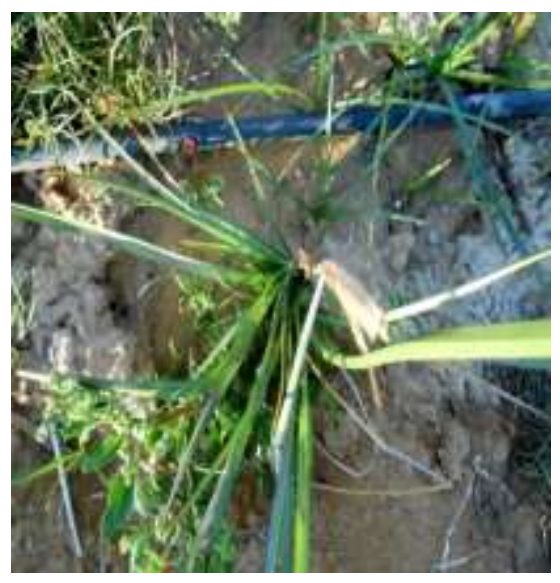

Fig 1. Growing vetiver grass in May

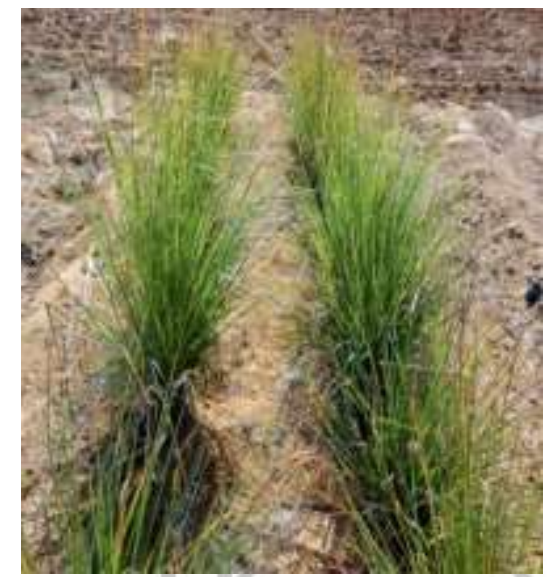

Fig 2. Growing vetiver grass in November

\section{Chemical analysis}

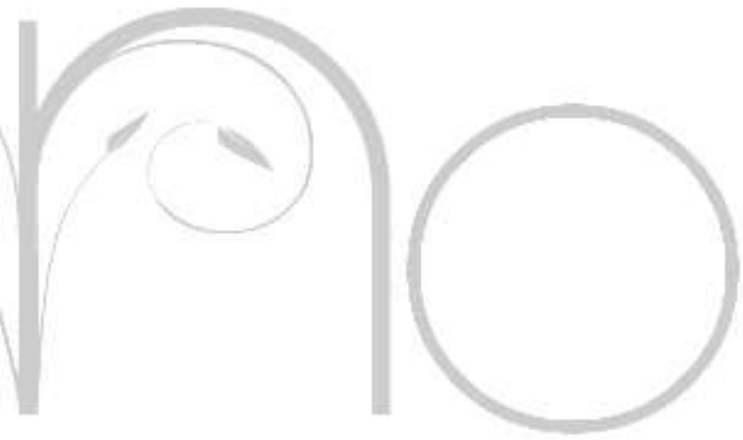

Proximate analysis (DM\%, CP\%, CF\%, EE\% and Ash \%) of vetiver hay, clover hay, concentrate mixture and the experimental diets (D1, D2 and D3) were conducted according to A.O.A.C. (1990). Fiber fractions [neutral detergent fiber (NDF) and acid detergent fiber (ADF) were determined according to Goering and Van Soest (1991). The NFC (non-fiber carbohydrate) was calculated as: NFC= 100-(CP + NDF + EE + Ash) and TDN (total digestible nutrient) was calculated as follow:

TDN = 0.479 NDF + 0.704 NFC + 1.594 EE + 0.714 CP for forage (Jayanegara et al., 2019)

$\mathrm{TDN}=0.323 \mathrm{NDF}+0.883 \mathrm{NFC}+1.829 \mathrm{EE}+0.885 \mathrm{CP}$ for concentrate (Jayanegara et al., 2019)

While metabolizable energy (ME) was calculated as follow: $M E(M \mathrm{cal} / \mathrm{kg} D M)=(\operatorname{TDN} \times$ 3.6) /100 (Church and Pond, 1982).

Determine of saponins was according to the method of Segal et al. (1966). Total tannins (TT) were determined gravimetrically with copper acetate method according to Balbaa et al. (1986). Sodium (Na) and potassium (K) were determined by using the standard 2020 November Edition | www.jbino.com | Innovative Association 
flame photometry (Jackson, 1958). While calcium was determined by spectrophotometer (Gindler and King, 1972). Inorganic phosphorus was determined by atomic absorption spectrophotometer according to Chapman and Pratt (1961).

\section{In vitro gas procedure}

Three adult rams (mean weight $50 \pm 0.8 \mathrm{~kg}$ ) were used as a source of rumen liquor which was collected before feeding in pre-warmed insulted bottles then mixed and squeezed through 3-layers cheesecloth under continuous flushing with $\mathrm{CO} 2$ and immediately transported to laboratory at $39^{\circ} \mathrm{C}$ for in vitro gas production procedure according to Menke and Steingass (1988). Each treatment was tested in 6 replicates accompanied by blank vessels (no substrate). $400 \mathrm{mg}$ of milled substrate was added to the incubation vessels of $100 \mathrm{~mL}$ capacity. Each vessel was filled with $40 \mathrm{~mL}$ of the incubation medium consisted of $292 \mathrm{mg} \mathrm{K} 2 \mathrm{HPO} 4,240 \mathrm{mg} \mathrm{KH} 2 \mathrm{PO} 4,480 \mathrm{mg}(\mathrm{NH} 4) 2 \mathrm{SO} 4,480 \mathrm{mg} \mathrm{NaCl}, 100 \mathrm{mg}$ $\mathrm{MgSO} 4 \times 7 \mathrm{H} 2 \mathrm{O}, 64 \mathrm{mg} \mathrm{CaCl} 2.2 \mathrm{H} 2 \mathrm{O}, 4 \mathrm{mg} \mathrm{Na} 2 \mathrm{CO} 3$ and $600 \mathrm{mg}$ cysteine hydrochloride per 1 liter of distilled water and dispensed anaerobically in the 1:4 (v/v) ratio. Then the treatments were incubated at $39^{\circ} \mathrm{C}$ for $48 \mathrm{~h}$.

The average of the volume of gas produced from the blanks was deducted from the volume of gas produced per sample. After $48 \mathrm{~h}$ digestion, the samples were transferred into test tubes and centrifuge for $1 \mathrm{~h}$ in order to obtain the residues which was then filtered using Whatman No 4 filter paper temperature ranges between $30^{\circ} \mathrm{C}$ and $42^{\circ} \mathrm{C}$ being the by gravity and the residues placed in for drying at $65^{\circ} \mathrm{C}$ for $24 \mathrm{~h}$. The dry residues were weighed and digestibility calculated using the equation as follows:

$\operatorname{IVDMD}(\%)=[($ initial DM input - DM residue - Blank) / initial DM input $] * 100$

Substrate residues after $48 \mathrm{~h}$ of incubation were dried and analyzed for proximate analysis.

\section{Statistical analysis}

Data obtained from each diet were analyzed for variance using an ANOVA procedure according to SAS (2000) using the following model: Yij $=\mu+$ ai $+\varepsilon i j$

where Yij is observation, $\mu$ is overall mean, ai is the level of plant inclusion ( $i=1$ to 3 ), and عij is error. Tukey's test was used for the multiple comparisons among mean values for the four plants and the significance level was set at $p<0.05$.

\section{Result and discussion}

\section{Chemical composition, minerals content and nutritive value of the experimental plants}

Proximate analysis of clover hay, vetiver grass and concentrate mixture (CM) as energy feed supplements are showen in table (1). The results showed that clover hay and vetiver grass had comparable values of CP content (126 and $100 \mathrm{~g} / \mathrm{kg} \mathrm{DM}$, respectively). The values obtained can meet the daily protein requirement of $70 \mathrm{~g} / \mathrm{kg}$ DMl 100 for grazing animals (Okaraonye and Ikewuchi, 2009). As vetiver grass contained higher concentrations of lipids (EE) and non-fiber carbohydrate (NFC). Therefore, the nutritive value as total digestible nutrient (TDN) of vetiver grass surpassed their mates of clover hay (50.7 vs 57, respectively). The same trend of TDN was observed for metabolizable energy 
(ME) as well. Metabolizable energy pattern could be attributed to TDN \% of each feedstuff. These results suggested that vetiver grass has suitable crude protein and energy contents that could be consider high quality forage for animal feeding system.

On the other hand, the levels of total tannins and saponin in vetiver 161 and $63 \mathrm{~g} / \mathrm{kg} \mathrm{DM}$, respectively) were higher than their values in clover hay $(19$ and $44 \mathrm{~g} / \mathrm{kg} \mathrm{DM}$, respectively). From the level obtained in the present study, it is not likely that the saponnin content of vetiver will affect its nutritional potentials to any significant extent (Falola et al. 2013). While the level of total tannins in vetiver grass could have adversely affect digestibility in sheep and cattle as reported by Diagayette and Huss (1981). Goat is known to tolerant about $90 \mathrm{~g} / \mathrm{kg}$ DM dietary tannin (Natis and Malachek, 1981).

Data in table 2. showed that clover hay surpassed vetiver grass at all minerals concentrations. For both plants, $\mathrm{P}$ and $\mathrm{Ca}$ values are within the recommended requirement for maintenance and non-lactating goat (Kearl, 1982). However, $\mathrm{P}$ and $\mathrm{Ca}$ content in vetiver grass were below the recommended requirements for lactating and growing goat (Kearl, 1982). The results of all nutrients components and TDN values were in agreement with Abdou et al. (2011) for clover hay and disagree with Falola et al. (2013) and Ahmadi Beni et al. (2014) for vetiver grass that could be attributed to different climatic, environmental and stage of growth factors.

\section{Chemical composition and nutritive value of the experimental diets}

Data in table 3. Showed that Chemical composition in the term of DM, CP, CF, NDF, ADF, EE and NFE were comparable for all experimental diets (D1, D2 and D3). Diet 3 (70\% CM: $30 \%$ vetiver grass ) had higher values of DM, CP and NFC 1910.134 and $386 \mathrm{~g} / \mathrm{kg}$ DM, respectively), than those in diet2 and diet1. On the other side, it is noticeable that increasing the level of CM in the diets reflected the decrease in CF, NDF, ADF and EE values. While TDV values was nearly similar for D1, D2 and D3 (582, 59.1 and 59.8, respectively). Similar trends were observed by Kim et al. (2018) when they study the effect of different concentrate diet levels on determination of in vitro rumen fermentation and methane production.

\section{In vitro nutrients digestibility and gas production of the experimental diets}

The effect of different levels of vetiver grass (30,50 and $70 \%$ ) in the experimental diets are shown in table (4). Increasing the level of vetiver into diets had no effect $(\mathrm{P}<0.05)$ on dry matter, organic matter and NDF digestibility. While high level of vetiver grass (70\% of DM) in dietl have negative effect on crude protein digestibility. The lower digestibility of protein in Dl could be attributed to the higher concentration of total tannins and saponin in vetiver grass (shown in table 1.) that could reduce the nutrients digestibility (Ghandour et al. 2014). In this respect, Mousa (2011) reported low digestibility of acacia and ascribed that to the inhibitory effect of tannin on ruminal microbial activity.

The results of DM, OM, NDF digestibility was in agreement with Chen et al. (2010) and Ghorbani et al. (2011) who suggested that the level of concentrates have no adverse effect on nutrient digestibility.

Total gas production significantly varied among the experimental diets, the highest value was recorded for D1 (30\% CM + 70\% vetiver grass) while the lowest values was recorded for D3 (70\% CM + 30\% vetiver grass). It is noticeable the positive effect on vetiver grass on total gas production. It mainly attributed to higher tannin and saponin contents for 
vetiver grass that reflect in reduction of total gas production and total number of ruminal Bacteria as well (Makkar 2003). The present study suggest that

1- vetiver grass contained adequate amount of crude protein and metabolizable energy for livestock requirements

2- The anti-nutritional contents as total tannin and saponin were below the toxic level 3- Diet included vetiver grass up to $50 \%$ of dry matter had the best nutrient digestibility and reduces total gas emission.

\section{Conclusion}

From the previous results we could conclude that vetiver grass had a pronounced nutritive value as a fodder plants, had sufficient protein and metabolizable energy, could reduce emission of total gas production and could be used up to $50 \%$ in small ruminant diet. Further in vivo studies are needed to confirm in vitro results.

Table 1. Chemical composition, fiber fraction and nutritive values of clover hay $v s$ vetiver grass

\section{Chemical composition $(\mathrm{g} / \mathrm{kg} \mathrm{DM})$}

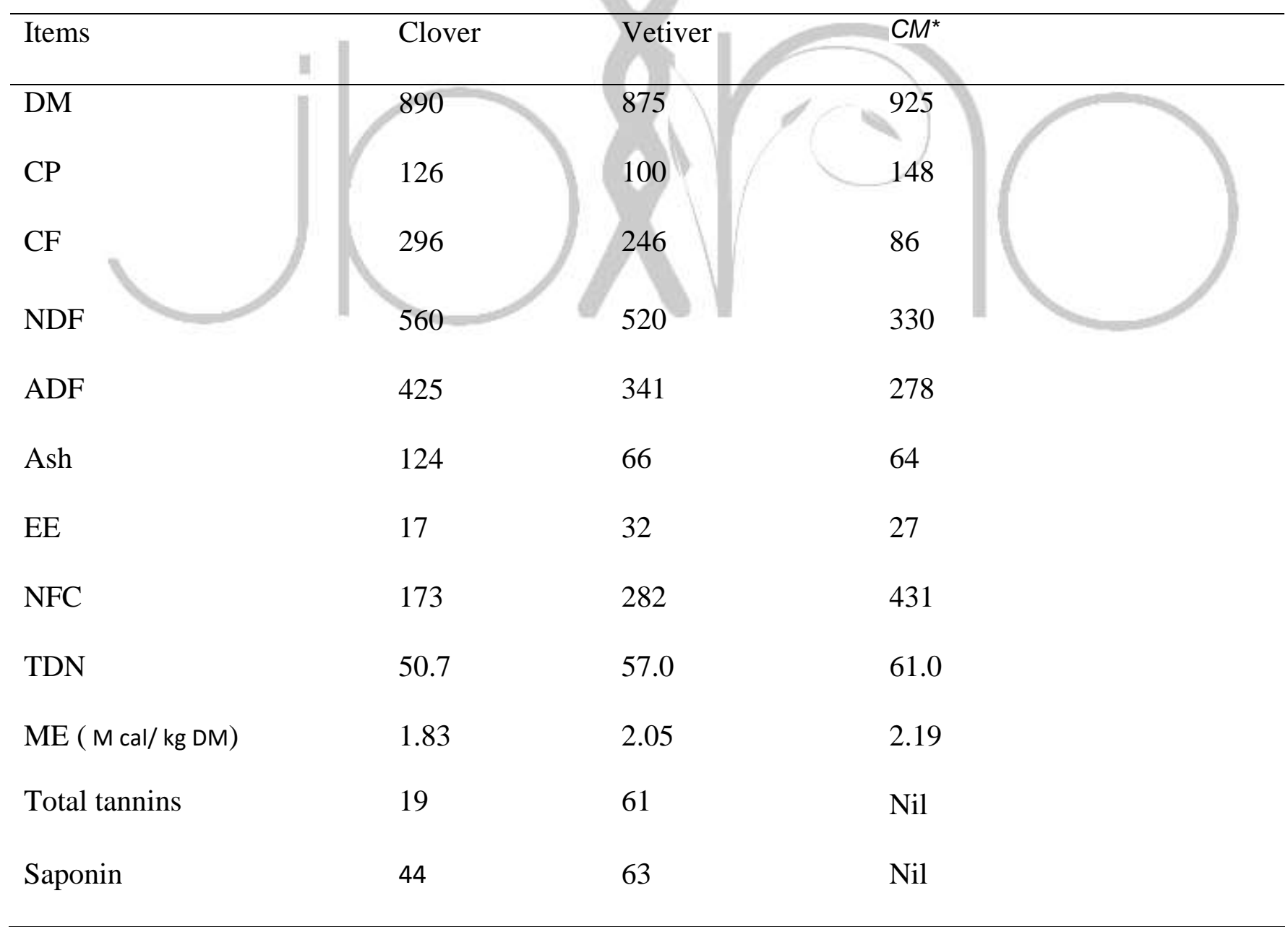

*CM: concentrate mixture

$\mathrm{DM}=$ dry matter, $\mathrm{CP}=$ crud protein, $\mathrm{CF}=$ crud fiber, $\mathrm{NDF}=$ nutrient detergent fiber, $\mathrm{ADF}=$ acid detergent fiber, $\mathrm{EE}$ : ether extract, NFC: non-fiber carbohydrate and TDN: total digestible nutrient 
Table 2. Some minerals contents of clover hay $v s$ vetiver grass.

\begin{tabular}{llc}
\hline Items & Clover hay & Vetiver grass \\
\hline $\mathrm{Na}(\mathrm{g} / \mathrm{kg} \mathrm{DM})$ & 14.8 & 8.4 \\
$\mathrm{~K}(\mathrm{~g} / \mathrm{kg} \mathrm{DM})$ & 17.3 & 13.6 \\
$\mathrm{Ca}(\mathrm{g} / \mathrm{kg} \mathrm{DM})$ & 9.3 & 5.2 \\
$\mathrm{P}(\mathrm{mg} / \mathrm{kg})$ & 6.6 & 2.6 \\
\hline $\mathrm{Na}:$ sodium ,K :potassium, Ca: calcium, P: phosphorus. & \\
\hline
\end{tabular}

Table 3: Chemical composition and nutritive values of the experimental diets.

Chemical composition (g/kg DM)

\begin{tabular}{lccc}
\hline Items & D1 & D2 & D3 \\
\hline DM & 890 & 900 & 910 \\
CP & 114 & 124 & 134 \\
CF & 198 & 166 & 134 \\
NDF & 463 & 425 & 387 \\
ADF & 322 & 310 & 297
\end{tabular}




$\begin{array}{lrrr}\text { EE } & 30.5 & 29.5 & 28.5 \\ \text { NFC } & 327 & 357 & 386 \\ \text { TDN } & 58.2 & 59.1 & 59.8\end{array}$

$\mathrm{D} 1: 30 \% \mathrm{CM}+70 \%$ vetiver grass,

D2: $50 \% \mathrm{CM}: 50 \%$ vetiver grass

D3: $70 \% \mathrm{CM}: 30 \%$ vetiver grass

$\mathrm{DM}=$ dry matter, $\mathrm{CP}=$ crud protein, $\mathrm{CF}=$ crud fiber, $\mathrm{NDF}=$ nutrient detergent fiber, $\mathrm{ADF}=$ acid detergent fiber, $\mathrm{EE}$ : ether extract, NFC: non-fiber carbohydrate and TDN: total digestible nutrient

Table 4. In vitro nutrients digestibility and cumulative gas production of the experimental diets.

D1 D2 D3

\begin{tabular}{lccc}
\hline IVDMD & $49.8 \pm 1.8$ & $53.2 \pm 2.7$ & $54.1 \pm 2.4$ \\
IVOMD & $56.8 \pm 3.9$ & $52.3 \pm 4.8$ & $55.5 \pm 1.2$ \\
IVNDFD & $36.7 \pm 6.5$ & $41.3 \pm 4.5$ & $42.6 \pm 2.0$ \\
IVCPD & $12.8^{\mathrm{b}} \pm 5.6$ & $14.2^{\mathrm{a}} \pm 6.0$ & $15.6^{\mathrm{a}} \pm 8.5$ \\
& $154.8^{\mathrm{b}} \pm 12.5$ & $167.3^{\mathrm{ab}} \pm 18.6$ & $171.3^{\mathrm{a}} \pm 13.7$
\end{tabular}

a,b Means having different superscripts within the same row differed significantly $(P<0.05)$, otherwise no significant differences were detected

$\mathrm{D} 1: 30 \% \mathrm{CM}+70 \%$ vetiver grass

D2: $50 \% \mathrm{CM}: 50 \%$ vetiver grass

D3: $70 \% \mathrm{CM}: 30 \%$ vetiver grass

IVDMD = in vitro dry matter digestibility, IVOMD = in vitro organic matter digestibility, IVNDFD = in vitro nutrient detergent fiber digestibility, IVCPD = in vitro crud protein digestibility. TGP: total gas production.

\section{References}

Abdou Ahlam R, Eid E Y, El-Essawy Abeer M, Fayed Afaf M, Helal H G and. El-Shaer H M. 2011 . Effect of Feeding Different Sources of Energy on Performance of Goats Fed Saltbush in Sinai. J Amer Sci. 7(1):1040-1050.

Ahmadi Beni M, Gharmakher H N , Azimi M S, Maramaei M J . 2014.Investigation of Forage Quality of Vetiveria zizanioides in Semi-Steppe Region of Maravehtappeh, Golestan Province, Iran. Journal of Rangeland Science 4(4):287-297. 
Akhzari D, Alireza lldoromi A and Dashti Marvili M. 2013. Effects of salinity on seedling growth and physiological traits of Vetiver grass (Vetiveria zizanioides Stapf.). J. Rangeland science. 3(3):191-198.

AOAC : Association of Official Analytical Chemists. 2007. Official Methods of Analysis, 19th Edition, Washington, USA.

Balasankar D, Vanilarasu K, Selva Preetha P, Rajeswari S, Umadevi M, Debjit Bhowmik.2013. Traditional and Medicinal Uses of Vetiver. Journal of Medicinal Plants Studies. 1 (3):191:200.

Balbaa S I. 1986. Chemistry of crude drug. Laboratory Manual Faculty of Pharmacy. Cairo University. 195 pp.

Chapman H I and Pratt P F. 1961. Methods analysis for soils, plants and waters. Uni. California. Kerkelcy. 309.

Chen S, Paengkoum P, Xia X, Na-Lumpang P. 2010. Effects of dietary protein on ruminal fermentation, nitrogen utilization and crude protein maintenance in growing Thaiindigenous beef cattle fed rice straw as roughage. J Anim Vet Adv.9:2396-2400.

Chen $\mathrm{H}$. 1998. The overview of vetiver research and cultivation in China. Jour. Water and Soil Conservation. 18(3): 77-81.

Church D C and Pond W G. (1982): Basic Animal Nutrition and Feeding, 2 nd .Johnwiley and Sons, New York, U S A.

Diagayette M and Huss W. 1981. Tannin contents of African pasture plants. Effects on analytical data and in vitro digestibility. Anim. Res. Dev. 15: 79-90.

Ghandour M M A, Fayed Afaf M, Abdul-Aziz G M and Hanafy M A. 2014. Effect of Using Polyethylene Glycol or Sodium Bentonite on Performance of Sheep Fed Acacia saligna. World Applied Sciences Journal 32 (11): 2309-2316.

Ghorbani B, Ghoorchi T, Amanlou H, Zerehdaran S. 2011. Effects of using monensin and different levels of crude protein on milk production, blood metabolites and digestion of dairy cows. Asian Australas J Anim Sci. 24:65-72

Gindler M and King J D. 1972. Rapid colorimetric determinatation of calcium in biologicfluids with methylthymol blue. Am. J. Clinc. Path., 58:376-382.

Jackson M L. 1958. Soil Chemical Analysis. Prentice-Hall Inc. Englewood Cliffs, NJ, 498 p. 
Jayanegara A, Ridla M, Nahrowi and Laconi E B. 2019. Estimation and validation of total digestible nutrient values of forage and concentrate feedstuffs. IOP Conf. Ser.: Mater. Sci. Eng. 546.

Kearl L C. 1982. Nutrient requirements of ruminants in developing countries.1stEdn. International Feedstuffs Institute. Utah State Univ., Logan, Utah, USA.

Kim S, Mamuad L, Kim E, Sung H, Bae G, Cho K, Lee C, Lee S. 2018. Effect of different concentrate diet levels on rumen fluid inoculum used for determination of in vitro rumen fermentation, methane concentration, and methanogen abundance and diversity.Italian Journal of Animal Science. 17(2):359-367.

Lavania U C. 2003. Other uses of vetiver: Part II. Vetiver oil. Proceedings of the Third International Conference on Vetiver and Exhibition, Guangzhou, China.

Makkar H P S, Bluemmel M, Borowy, NK, Becker K. 1993. Gravimetric determination of tannins and their correlations with chemical and protein precipitation methods. J. the Sci. Food and Agric. 61: 161-165.

Makkar H P S. 2003. Effects and fate of tannins in ruminant animals, adaptation to tannins, and strategies to overcome detrimental effects of feeding tannin-rich feeds. Small Rumin. Res. 49:241-256.

Menke K H and Steingass H. 1988. Estimation of the energy feed value obtained from chemical analysis and in vitro gas production using rumen fluid. Anim. Res. Dev., 28: 7-55.

Mousa M R M. 2011. Effect of feeding Acacia as supplements on the nutrient digestion, growth performance, carcass traits and some blood constituents of Awassi lambs under the conditions of north Sinai. Asian Journal of Animal Sciences. 5:102-117.

Natis A S and Malachek J C.1981. Digestion and utilization of nutrients oak browse by goats. J. Anim. Sci., 52: 283-288.

Okaraonye C C and Ikewuchi J C. 2009. Nutritional and Antinutritional components of Pennisetum purpureum (schumach). Pak. J. Nutr., 8: 32-34.

SAS Institute. SAS user's guide: statistics (Vol. 2). 1985. SAS Institute, Cary, NC.

Segal R, Mansour M, Zaitschek D V. 1966. Effect of ester groups on the haemolytic action of some saponins and sapogenins. Biochemic. Pharmacol. 15, 1411-1416.

Van Soest P J, Robertson J B, Lewis B A. 1991. Methods for dietary fiber, neutral detergent fiber, neutral non-starch polysaccharides in relation to animal nutrition. J Dairy sci.74:35833597. 